\title{
FAKTOR-FAKTOR YANG MEMPENGARUHI SISTEM PENGAWASAN PENGELOLAAN KEUANGAN DESA (STUDI KASUS WILAYAH KABUPATEN BOGOR)
}

\author{
KETERANGAN ARTIKEL \\ Riwayat Artikel \\ Diterima: 1 Mei 2019 \\ Direvisi: 1 Juni 2019 \\ Disetujui: 31 Juni 2019 \\ Klasifikasi JEL \\ R5, R51
}

\author{
Rochman Marota ${ }^{\mathbf{1}}$, Asep Alipudin ${ }^{2}$ \\ Universitas Pakuan, Bogor \\ Email: rochmanmarota@yahoo.com
}

\section{Keywords: Village Law, Monitoring System, Village Financial Management}

Kata Kunci: Undang-Undang Desa, Sistem Pengawasan, Pengelolaan Keuangan Desa

\section{ABSTRACT}

The Village Law gives new meaning related to trust by seeing the village as an institution that is equal to the regional government. The village not only as an institution providing letters or government accomplices, but an institution that independently and has the task of maintaining the welfare of the small unit in the community. These consequences provide a view of the professionalism of performance that can be monitored transparently and accountably. The urgency of this research lies in its objectives and benefits for the government and village officials, namely to provide a complete and factual picture of village supervision and finance from planning, management and accountability as well as strengthening the capabilities of village officials in managing funds and overseeing programs funded by village funds in a way and village development in general. This study concludes that there is a relationship between the stages of village financial management from the process of planning, implementing, administering and reporting to its monitoring system. The good village financial management process showed that the monitoring system was running well.

\section{ABSTRAK}

Undang-Undang Desa memberi makna baru terkait kepercayaan dengan memandang desa sebagai lembaga yang setara dengan pemerintah daerah. Desa tidak hanya dipandang sebagai lembaga menyediakan pengantar surat atau kaki tangan pemerintah melainkan lembaga yang secara mandiri dan mempunyai tugas menjaga kesejahteraan masyarakat unit kecil di lingkungannya. Konsekuensi ini memberikan pandangan akan adanya profesionalisme kinerja yang dapat dipantau secara transparan dan akuntabel. Urgensi penelitian ini terletak pada tujuan dan manfaatnya bagi pemerintahan dan aparat desa yaitu untuk memberikan gambaran yang lengkap dan faktual tentang pengawasan dan keuangan desa dari perencanaan, pengelolaan dan pertanggungjawabannya serta penguatan kapabilitas aparat desa dalam mengelola dana dan mengawasi program yang dibiayai oleh dana desa secara khusus serta pembangunan desa secara umum. Penelitian ini menyimpulkan bahwa terdapat hubungan antara tahapan pengelolaan keuangan desa dari mulai proses perencanaan, pelaksanaan, penatausahaan dan pelaporan terhadap sistem pengawasannya. Proses pengelolaan keuangan desa yang sehat menunjukkan sistem pengawasannya yang berjalan baik. 


\section{PENDAHULUAN}

Undang-Undang Nomor 6 Tahun 2014 beserta peraturan pelaksanaannya telah mengamanatkan pemerintah desa untuk lebih mandiri dalam mengelola pemerintahan dan berbagai sumber daya alam yang dimiliki, termasuk di dalamnya pengelolaan keuangan dan kekayaan milik desa. Dalam Perubahan Anggaran Pendapatan dan Belanja Negara (APBN-P) tahun 2015 telah dialokasikan Dana Desa sebesar \pm Rp 20,776 triliun kepada seluruh desa yang tersebar di Indonesia. Jumlah desa yang ada saat ini sesuai Permendagri 39 Tahun 2015 sebanyak 74.093 desa. Selain Dana Desa, sesuai UU Desa pasal 72, Desa memiliki Pendapatan Asli Desa dan Pendapatan Transfer berupa Alokasi Dana Desa; Bagian dari Hasil Pajak dan Retribusi Kabupaten/Kota; dan Bantuan Keuangan dari APBD Provinsi/ Kabupaten/Kota. Peran besar yang diterima oleh desa, tentunya disertai dengan tanggung jawab yang besar pula.

Kabupaten Bogor memiliki 40 kecamatan dan 428 desa/kelurahan. Hampir sebagian besar desa di Kabupaten Bogor sudah terklasifikasi sebagai desa swakarya yakni 237 desa dan 191 desa merupakan desa swasembada. Pendapatan Asli Daerah Kabupaten Bogor meningkat hingga 70 persen selama periode 2014 sampai 2018. Dari hanya Rp900 miliar pada 2014, hingga mencapai Rp1,56 triliun tahun 2018. Potensi desa di Kabupaten Bogor sampai saat ini semakin besar jika dilihat dari data tersebut.

Namun, pemerintah desa harus bisa menerapkan prinsip akuntabilitas dalam tata pemerintahannya, dimana semua akhir kegiatan penyelenggaraan pemerintahan desa harus dapat dipertanggungjawabkan kepada masyarakat desa sesuai dengan ketentuan. Peran dan tanggung jawab yang diterima oleh desa belum diimbangi dengan sumber daya manusia (SDM) yang memadai baik dari segi kuantitas maupun kualitas. Kendala umum lainnya yaitu desa belum memiliki prosedur serta dukungan sarana dan prasarana dalam pengelolaan keuangannya serta belum kritisnya masyarakat atas pengelolaan anggaran pendapatan dan belanja desa. Besarnya dana yang harus dikelola oleh pemerintah desa memiliki risiko yang cukup tinggi dalam pengelolaannya, khususnya bagi aparatur pemerintah desa.

Mahmudin (2016) menyatakan bahwa kekhawatiran besarnya alokasi dana desa terkait dengan kemampuan desa mengatur pengalokasian dana yang ada sehingga dikhawatikan akan terjadinya korupsi tingkat bawah. Tentunya hal tersebut bisa mempengaruhi pengelolaan keuangan desa. Kita lihat saja misalnya, selama ini ketika dilakukan pengawasan terhadap efektivitas pengelolaan keuangan desa, masih ada sejumlah permasalahan yang menjadi temuan diantaranya surat pertanggungjawaban (SPJ) yang belum memenuhi syarat formal dan material (Suyatno, 2015).

Kondisi tersebut terjadi disinyalir oleh kemampuan yang dimiliki kepala desa beserta aparaturnya yang masih rendah. Sebagaimana halnya diungkapkan oleh Thomas (2013) bahwa salah satu komponen kelemahan yang dimiliki oleh pemerintahan desa adalah kualitas sumber daya aparatur yang masih rendah sehingga menyebabkan rendahnya kemampuan dalam perencanaan tingkat desa yang berakibat pada kurangnya sinkronisasi antara output (hasil/keluaran) implementasi kebijakan dengan kebutuhan dari masyarakat yang merupakan input dari kebijakan. Oleh karena itu, diperlukan pengawasan yang ketat dalam pengelolaan keuangan desa.

\section{KAJIAN LITERATUR DAN PENGEMBANGAN HIPOTESIS Desa}

Desa menurut Undang-undang Nomor 6 Tahun 2014 menyebutkan bahwa desa adalah kesatuan masyarakat hukum yang memiliki batas wilayah yang berwenang untuk mengantur dan mengurus urusan pemerintah, kepentingan masyarakat setempat berdasarkan prakarsa masyarakat, hak asal usul, dan/atau hak tradisional yang diakui dan 
dihormati dalam sistem pemerintahaan Negara Kesatuan Republik Indonesia. Menurut kacamata politik sebagaimana dikutip oleh Anwar dan Jatmiko (2014), desa dipahami sebagai organisasi kekuasaan yang memiliki kewenangan tertentu dalam struktur pemerintahan negara.

Berdasarkan uraian di atas, dapat disimpulkan bahwa pemerintahan desa merupakan salah satu institusi pemerintahan yang melaksanakan pemerintahan di tingkat terendah yang keberadaaannya sudah diatur dalam perundang-undangan negara. Dengan demikian, adanya otonomi yang diberikan kepada desa akan semakin memberikan peluang bagi desa untuk terus memanfaatkan potensi yang dimilikinya demi kesejahteraan masyarakatnya.

\section{Sistem Pengawasan}

Menurut Peraturan Menteri Dalam Negeri No. 7 tahun 2008, pengawasan atas penyelenggaraan Pemerintahan Desa adalah proses kegiatan yang ditujukan untuk menjamin agar Pemerintahan Desa berjalan secara efisien dan efektif sesuai dengan rencana dan ketentuan peraturan perundangundangan. Menurut Cahyat (2004), dalam sebuah entitas atau organisasi, sistem pengawasan memegang peranan penting untuk memastikan bahwa segala sesuatunya berjalan sesuai dengan mandat, visi, misi, tujuan serta target-target organisasi. Sistem pengawasan memiliki dua tujuan utama yaitu akuntabilitas dan proses belajar. Dari sisi akuntabilitas, sistem pengawasan akan memastikan bahwa dana pembangunan digunakan sesuai dengan etika dan aturan hukum dalam rangka memenuhi rasa keadilan. Dari sisi proses belajar, sistem pengawasan akan memberikan informasi tentang dampak dari program atau intervensi yang dilakukan, sehingga pengambil keputusan dapat belajar tentang bagaimana menciptakan program yang lebih efektif.

\section{Pengelolaan Keuangan Desa}

Badan Pengawasan Keuangan dan Pembangunan - BPKP (2015) serta Ikatan Akuntan Indonesia Kompartemen Akuntan Sektor Publik, IAI - KASP (2015) memberikan pengertian tentang Keuangan Desa menurut pasal 71 ayat (1) UU Nomor 6 Tahun 2014 yaitu semua hak dan kewajiban Desa yang dapat dinilai dengan uang serta segala sesuatu berupa uang dan barang yang berhubungan dengan pelaksanaan hak dan kewajiban Desa. Pengelolaan Keuangan Desa adalah keseluruhan kegiatan yang meliputi perencanaan, pelaksanaan, penatausahaan, pelaporan, dan pertanggungjawaban keuangan desa.

Dengan berlakunya Undang-Undang Desa Nomor 6 Tahun 2014 memberikan kewenangan kepada desa untuk melakukan pengelolaan keuangan secara mandiri. Dalam regulasi tersebut diatur bagaimana pelaksanaan pengelolaan keuangan desa mulai dari yang bersifat umum sampai dengan penjelasan terperincinya. Dalam Peraturan Pemerintah Nomor 43 Tahun 2014 sebagaimana telah diubah dalam Peraturan Pemerintah Nomor 47 Tahun 2015 tentang Peraturan Pelaksanaan Undang-Undang Nomor 6 Tahun 2014 tentang Desa dijelaskan bahwa pengelolaan keuangan desa merupakan keseluruhan kegiatan yang meliputi perencanaan, pelaksanaan, penatausahaan, pelaporan dan pertanggungjawaban keuangan desa.

Pengelolaan keuangan desa
dilaksanakan dalam masa 1 (satu) tahun anggaran terhitung mulai tanggal 1 Januari sampai dengan 31 Desember. Sesuai Permendagri Nomor 113/2014 tentang Pedoman Pengelolaan Keuangan Desa disebutkan bahwa Pemegang Kekuasaan Pengelolaan Keuangan Desa adalah Kepala Desa atau sebutan nama lain yang karena jabatannya mempunyai kewenangan menyelenggarakan keseluruhan pengelolaan keuangan desa. Tugas dan kewenangan kepala 
desa dalam kaitan pengelolaan keuangan antara lain mencakup menetapkan kebijakan pengelolaan barang desa, menetapkan kebijakan pelaksanaan Anggaran Pendapatan dan Belanja (APB) Desa maupun menetapkan Bendahara Desa (Syachbrani, 2012).

\section{Perencanaan Keuangan Desa}

Pemerintah Desa

menyusun

perencanaan pembangunan desa sesuai dengan kewenangannya dengan mengacu pada perencanaan pembangunan kabupaten/kota. Perencanaan Pembangunan Desa meliputi Rencana Pembangunan Jangka Menengah (RPJM) Desa dan Rencana Kerja Pemerintah (RKP) Desa yang disusun secara berjangka dan ditetapkan dengan Peraturan Desa.

$\mathrm{H}_{1}$ : Perencanaan keuangan desa berpengaruh terhadap sistem pengawasan

\section{Pelaksanaan Keuangan Desa}

Dalam pelaksanaan keuangan desa, terdapat beberapa prinsip umum yang harus ditaati yang mencakup penerimaan dan pengeluaran. Prinsip itu diantaranya bahwa seluruh penerimaan dan pengeluaran desa dilaksanakan melalui Rekening Kas Desa.

$\mathrm{H}_{2}$ : Pelaksanaan keuangan desa berpengaruh terhadap sistem pengawasan

\section{Penatausahaan Keuangan Desa}

Penatausahaan Keuangan Desa adalah kegiatan pencatatan yang khususnya dilakukan oleh Bendahara Desa. Bendahara Desa wajib melakukan pencatatan terhadap seluruh transaksi yang ada berupa penerimaan dan pengeluaran.

$\mathrm{H}_{3}$ : Penatausahaan keuangan desa berpengaruh terhadap sistem pengawasan

\section{Pelaporan Keuangan Desa}

Dalam melaksanakan tugas, kewenangan, hak, dan kewajibannya dalam pengelolaan keuangan desa, kepala desa memiliki kewajiban untuk menyampaikan laporan. Laporan tersebut bersifat periodik semesteran dan tahunan, yang disampaikan ke Bupati/Walikota dan ada juga yang disampaikan ke BPD.

$\mathrm{H}_{4}$ : Pelaporan keuangan desa berpengaruh terhadap sistem pengawasan

\section{METODE PENELITIAN}

Penelitian ini dirancang sebagai penelitian kuantitatif dengan pendekatan studi kasus. Adapun sumber data yang digunakan yaitu data primer dan sekunder. Data primer diperoleh melalui wawancara secara langsung kepada kepala desa, sekretaris desa, bendara, dan anggota Badan Permusyawaratan Desa. Data sekunder diperoleh dari sumber penelitian dengan mempelajari referensi yang memiliki hubungan dengan sasaran penelitian. Setelah data penelitian diperoleh, maka dilanjutkan pada tahap teknik analisis data. Teknik analisis data yang meliputi empat proses yaitu pengumpulan data, reduksi data, penyajian data, dan analisis data serta penarikan kesimpulan.

\section{HASIL PENELITIAN DAN PEMBAHASAN} Analisis Data

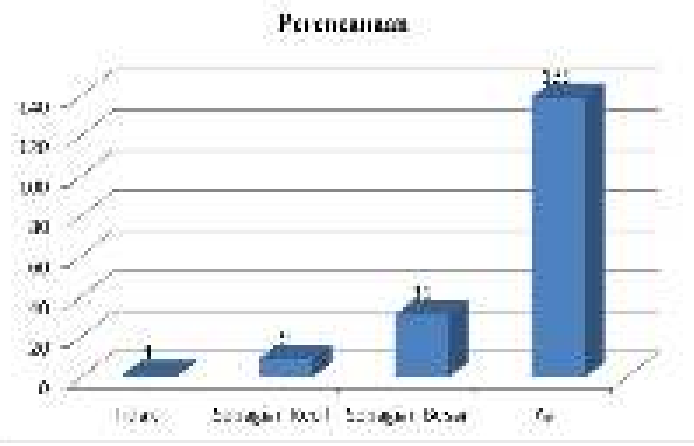

Gambar 1. Hasil pada Tahap Perencanaan

Berdasarkan grafik di atas, tahap perencanaan/penganggaran dari pengelolaan keuangan desa telah dinilai baik, karena ratarata responden menjawab ya/baik dari kuisioner yang telah disampaikan. Hal tersebut dibuktikan dari 30 responden yang diberikan masing-masing 6 pertanyaan sehingga totalnya 180, yang menjawab Ya dari pertanyaan pertama sebanyak 16 , yang 
menjawab Sebagian Besar 8, Sebagian Kecil 6, dan 0 yang menjawab Tidak. Total jawaban $\mathrm{Ya}$ dari 6 pertanyaan kepada 30 responden sebanyak 139,"31 untuk jawaban Sebagian Besar, "1 untuk jawaban Tidak" dan 0 untuk jawaban Sebagian Kecil.

Tahap perencanaan ini berarti Pemerintahan Desa telah melaksanakan dengan baik usulan anggaran sesuai dengan kegiatan yang sesuai dengan RPJM dan RKP Desa. Begitu pula proses dari perencanaan tersebut sampai dengan penyusunan rancangan Peraturan Desa tentang APB Desa, sampai ke tahap penetapan hasil evaluasi rancangan APB Desa tersebut. Pemerintahan Desa telah melakukan tahapan Perencanaan/Penganggaran dengan baik di dalam uraian kegiatannya.

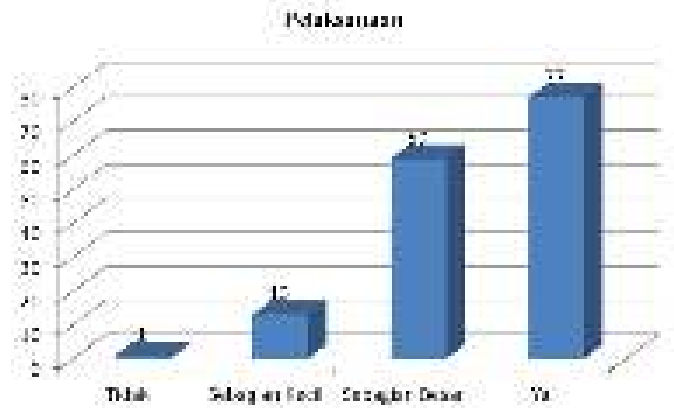

Gambar 2. Hasil pada Tahap Pelaksanaan

Berdasarkan grafik di atas menunjukan hasil yang baik tentang pelaksanaan Pemerintah Desa didalam penggunaan, penerimaan dan belanja anggaran Pemerintah Desa (APB Desa). Hasil penelitian dari kuisioner yang disampaikan kepada 30 responden yang terdiri dari 5 pertanyaan sehingga totalnya 150 untuk mewakili pelaksanaan dalam penggunaan, penerimaan dan belanja anggaran Pemerintah Desa mendapatkan hasil secara total 77 untuk jawaban Ya, 59 jawaban Sebagian Besar, sejumlah 13 jawaban Sebagian Kecil, dan 1 jawaban Tidak.

Tahap pelaksanaan ini mengartikan bahwa Pemerintah Desa telah melaksanakan penerimaan dan belanja anggaran secara baik dan penggunaannya sudah tepat dalam memenuhi kebutuhan yang berkaitan dengan program yang telah dilaksanakan oleh Pemerintah Desa dalam rangka kepentingan masyarakat desa terkait.

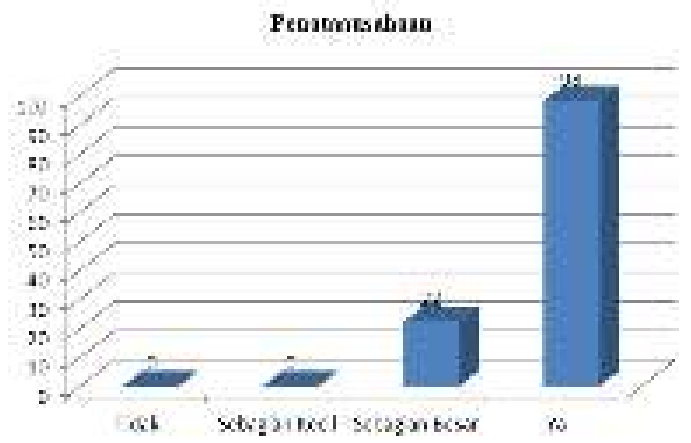

Gambar 3. Hasil pada Tahap Penatausahaan

Berdasarkan grafik di atas menunjukan hasil yang cukup baik tentang penatausahaan Pemerintah Desa didalam proses penerimaan dan pengeluaran yang diterima maupun dikeluarkan oleh Pemerintah Desa seperti adanya bukti berupa kuitansi dan bukti yang kan diterima pihak Desa dari Bank bila adanya transaksi mengenai dana tersebut. Hasil penelitian dari kuisioner yang diajukan yang memuat 4 pertanyaan kepada 30 responden sehingga terkumpul 120 jawaban, menunjukkan bahwa total ada 98 jawaban Ya, 22 jawaban "Sebagaian Besar, 0 jawaban" Sebagian Kecil, dan 0 jawaban Tidak.

Tahap penatausahaan ini merupakan tahapan yang bisa dibilang penting karena adanya bukti tertulis akan lebih mudah mendeteksi terjadinya pengeluaran dan penerimaan yang dilakukan oleh Pemeritah Desa didalam melaksanakan kegiatannya dana yang diterima dan dikeluarkan harus transparan dan ada bukti yang kuat terkait pemakaiannya. 


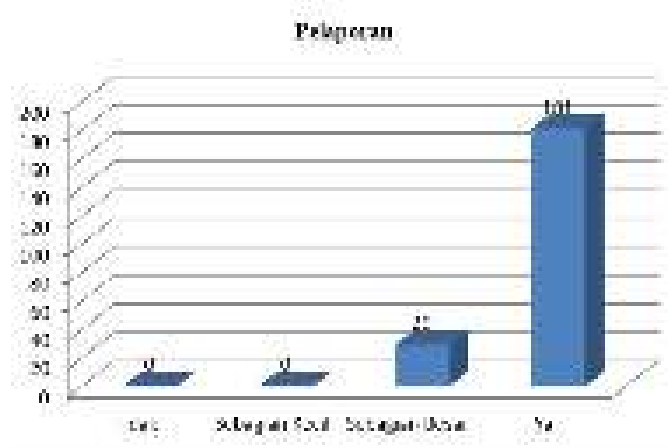

Gambar 4. Hasil pada Tahap Pelaporan

Berdasarkan grafik di atas menunjukan hasil yang baik tentang pelaporan / pertanggungjawaban Pemerintah Desa dalam melaporkan dana yang diterima maupun di keluarkan oleh Pemerintah Desa. Hasil penelitian di atas menunjukkan bahwa dari 7 pertanyaan yang mewakili aspek pelaporan kepada 30 responden, ada 181 jawaban Ya, 29 jawaban"Sebagaian Besar, 0 jawaban Sebagian Kecil, dan 0 jawaban"Tidak. Hasil tersebut baik dikarenakan dari segi pencatatan sampai dengan pelaporan pertanggungjawabannya sudah dilaksanakan secara benar dan baik sesuai dengan aturan yang telah di tetapkan.

Tahap pelaporan dan pertanggungjawaban ini merupakan hal penting karena apa yang telah diterima dan dikeluarkan Desa dalam menjalankan kegiatannya harus di perinci terkait apa saja hal-hal yang telah dilakukan. Selain itu tahap pelaporan / pertanggungjawaban ini tentunya harus ada persetujuan dari Kepala Desa yang bersangkutan yang sifatnya artinya hal-hal yang dilaporkan sudah benar dan bisa dipertanggungjwabankan kebenarannya.

Tahap 1. Hasil Uji Determinasi

\begin{tabular}{lllrr}
\hline Model & $\mathbf{R}$ & $\begin{array}{l}\mathbf{R} \\
\text { Square }\end{array}$ & $\begin{array}{l}\text { Adjusted } \\
\text { R Square }\end{array}$ & $\begin{array}{l}\text { Std. } \\
\text { Error of } \\
\text { The } \\
\text { Estimate }\end{array}$ \\
\hline 1 & $.821^{\text {a }}$ & .675 & .623 & .66667 \\
\hline a. & Predictors: & (Constant) & $\begin{array}{l}\text { Perencanaan, } \\
\text { Pelaksanaan, Penatausahaan, dan Pelaporan }\end{array}$
\end{tabular}

Koefisien determinasi (R2) bertujuan untuk mengukur kemampuan variabel-variabel independen dalam menjelaskan variasi variabel dependen. Nilai R2 yang semakin mendekati 1 berarti variabel-variabel independen semakin mampu menjelaskan variasi variabel dependen.

Berdasarkan hasil uji di atas, terlihat bahwa nilai R-squared adalah sebesar 0.821 atau $82,1 \%$. Hal ini berarti bahwa di dalam penelitian ini variabel-variabel di dalam penelitian ini yaitu Perencanaan, Pelaksanaan, Penatausahaan dan Pelaporan dapat menjelaskan variabel Sistem Pengawasan sebesar $82,1 \%$ sedangkan $17,9 \%$ dijelaskan oleh variabel-variabel lain yang tidak terdapat di dalam penelitian ini.

\section{Uji F}

Tabel 2. Hasil Simultan (Uji F)

\begin{tabular}{lrrrrr}
\multicolumn{7}{c}{ ANOVA $^{\text {a }}$} & \multicolumn{2}{c}{ Model } & $\begin{array}{c}\text { Sum of } \\
\text { Squares }\end{array}$ & Df & $\begin{array}{c}\text { Mean } \\
\text { Square }\end{array}$ & F & Sig. \\
\hline 1 Regression & 23.055 & 4 & 5.764 & 12.969 & $.000^{\mathrm{b}}$ \\
\hline Residual & 11.111 & 25 & .444 & & \\
\hline Total & 34.167 & 29 & & & \\
\hline
\end{tabular}

a. Dependent Variable: Sistem Pengawasan

b. Predictors: (Constant) Perencanaan, Pelaksanaan, Penatausahaan, dan Pelaporan

Uji F dikenal dengan uji serentak atau uji model, yaitu uji untuk melihat bagaimanakah pengaruh semua variabel bebasnya secara bersama-sama terhadap variabel terikatnya. 
Berdasarkan hasil perhitungan diatas diperoleh nilai signifikansi 0,000 dan signifikan pada 0,05. Hal ini berarti Perencanaan, Pelaksanaan, Penatausahaan dan Pelaporan secara bersama-sama (simultan) berpengaruh terhadap Sistem Pengawasan dalam pengelolaan keuangan Desa.

Uji t

Tabel 3. Hasil Uji Parsial (Uji t)

Coefficients $^{a}$

\begin{tabular}{|c|c|c|c|c|c|c|}
\hline \multicolumn{2}{|r|}{ Model } & \multicolumn{2}{|c|}{ Unstandardized Coefficients } & \multirow{2}{*}{$\begin{array}{c}\begin{array}{c}\text { Standardized } \\
\text { Coefficients }\end{array} \\
\text { Beta }\end{array}$} & \multirow[t]{2}{*}{$\mathrm{t}$} & \multirow[t]{2}{*}{ Sig. } \\
\hline & & B & Std. Error & & & \\
\hline \multirow[t]{5}{*}{1} & (Constant) & 4.362 & 2.767 & & 1.576 & .128 \\
\hline & Perencanaan & -.011 & .121 & -.015 & -.093 & .926 \\
\hline & Pelaksanaan & -.003 & .068 & -.006 & -.041 & .968 \\
\hline & Penatausahaan & .313 & .255 & .302 & 1.229 & .231 \\
\hline & Pelaporan & .382 & 169 & .550 & 2.254 & .033 \\
\hline
\end{tabular}

a. Dependent Variable: Sistem Pengawasan

Uji $t$ berfungsi untuk menunjukkan seberapa jauh suatu variabel independen mempengaruhi suatu variabel dependen. Pengujian di dalam penelitian dilakukan dengan menggunakan tingkat signifikansi 0.05 dan 2 sisi $(0.05 / 2=0.025)$.

Berdasarkan hasil uji $\mathrm{t}$ di atas, berikut adalah interpretasi atas hasil uji tersebut:

1. Ketentuan pengambilan hipotesis diterima atau ditolak didasarkan pada besarnya nilai signifikansi. Jika signifikansi lebih kecil atau sama dengan $0,05(\leq 0,05)$ maka hipotesis diterima. Hasil dari perhitungan tersebut menjelaskan bahwa nilai signifikansi sebesar 0,926. Artinya variabel Perencanaan tidak berpengaruh terhadap Sistem Pengawasan, tetapi dapat membantu proses Pengawasan Pengelolaan Keuangan Desa.

2. Hasil uji t kedua yaitu menunjukan hasil sebesar 0,968, hasil penelitian tersebut menjelaskan bahwa variabel Pelaksanaan tidak berpengaruh terhadap Sistem Pengawasan, tetapi dapat membantu proses Pengawasan Pengelolaan Keuangan Desa.

3. Hasil uji t ketiga memiliki nilai signifikansi sebesar 0,231, hasil dari perhitungan tersebut menjelaskan bahwa variabel Penatausahaan tidak berpengaruh terhadap Sistem Pengawasan, tetapi membantu dalam proses Pengawasan Pengelolaan Keuangan Desa.

4. Hasil uji $t$ keempat memiliki nilai signifikansi sebesar 0,033 , hasil dari perhitungan tersebut menjelaskan bahwa variabel Pelaporan berpengaruh terhadap Sistem Pengawasan, sehingga sangat membantu dalam proses Pengawasan Pengelolaan Keuangan Desa.

Berdasarkan uraian di atas, pemerintah desa wajib melaksanakan pengelolaan keuangan desa secara transparan, akuntabel dan partisipatif. Hal ini dilakukan mengingat adanya kewajiban untuk melaporkan kinerjanya kepada pemerintah di atasnya. Sebagaimana diungkapkan oleh Mardiasmo (2002) bahwa pelaporan kinerja merupakan bentuk kewajiban agen (pemerintah desa) untuk mempertanggungjawabkan, menyajikan, melaporkan serta mengungkapkan segala macam aktivitas kepada prinsipal (pemerintah pusat) dimana prinsipal tentunya memiliki hak dan kewenangan untuk meminta 
pertanggungjawaban tersebut. Dengan demikian, jika dalam proses pengelolaan dana desa sudah dilaksanakan sesuai peraturan perundang-undangan maka semua kegiatan pemerintahan desa dirasa dapat berhasil. Untuk mendukung pengelolaan keuangan desa yang baik, menurut Astini et.al (2019) diperlukan pelatihan keuangan desa untuk meningkatkan pemahaman aparat desa dalam pengelolaan keuangan desa. Selain itu, staf desa harus meningkatkan komitmen organisasi dalam pemerintahan desa.

\section{PENUTUP}

Penelitian ini menyimpulkan bahwa terdapat hubungan antara tahapan pengelolaan keuangan desa dari mulai proses perencanaan, pelaksanaan, penatausahaan dan pelaporan terhadap sistem pengawasannya. Apabila proses pengelolaan keuangan desa telah dilakukan dengan baik, maka sistem pengawasannya dapat berjalan baik pula. Penelitian ini terbatas atas desa dalam beberapa kecamatan yang ada di Kabupaten Bogor. Hasil penelitian ini memperkuat penelitian terdahulu yang dilakukan Gayatri et.al (2017) yang meneliti tentang pengaruh transparansi dan akuntabilitas terhadap pengelolaan keuangan dana desa, dimana transparansi yaitu terbukanya akses bagi masyarakat untuk memperoleh informasi mengenai perencanaan, pelaksanaan, dan pertanggungjawaban pengelolaan dana desa; dan akuntabilitas yaitu pelaporan dan pertanggungjawaban tim pelaksana pengelolaan dana desa kepada masyarakat. Saran pada penelitian berikutnya adalah perluasan obyek penelitian yaitu seluruh desa yang ada di Kabupaten Bogor sehingga dapat dibuat suatu generalisasi atas sistem pengawasan pengelolaan keuangan desa.

\section{REFERENSI}

Anwar, M. dan Jatmiko, B. (2014). Kontribusi Dan Peran Pengelolaan Keuangan Desa Untuk Mewujudkan Anggaran
Pendapatan Dan Belanja Desa Yang Transparan Dan Akuntabel (Survei Pada Perangkat Desa Di Kecamatan Ngaglik, Sleman, Yogyakarta). Jurnal Akmenika, Vol. $11 \mathrm{hlm}$. 387-410.

Astini Y, Fauzi AK, dan Widowati. (2019). Determinan yang Mempengaruhi Keberhasilan Pengelolaan Keuangan Desa. Valid Jurnal IImiah, Vol. 16 (1) hlm. 29-47.

Badan Pengawasan Keuangan dan Pembangunan. (2015). Petunjuk Pelaksanaan Bimbingan \& Konsultasi Pengelolaan Keuangan Desa. Jakarta: Deputi Bidang Pengawasan Penyelenggaraan Keuangan Daerah. Jakarta).

Cahyat, A. (2004). Sistem Pengawasan Terhadap Penyelenggaraan Pemerintah Daerah Kabupaten: Pembahasan Peraturan Perundangan di Bidang Pengawasan. Bogor: Center for International Forestry Research: Poverty \& Decentralization Project CIFOR (Center for International Forestry Research).

Gayatri, Latrini Made Y. dan Sari, Widhiyani Ni Luh. (2017). Transparansi dan Akuntabilitas Pengelolaan Keuangan Dana Desa untuk Mendorong Kemandirian Masyarakat Pedesaan, Jurnal Ekonomi Kuantitatif Terapan, Vol. 10 (2) hlm. 175-182.

Ikatan Akuntan Indonesia - Kompartemen Akuntan Sektor Publik. (2015) Pedoman Asistensi Akuntansi Keuangan Desa. Jakarta: Penerbit IAI - KASP.

Mahmudin, M. A. (2016). Manajemen Pemerintahan Desa Dalam Pengelolaan Dana Desa. Bogor: Laporan Studi Pustaka Institut Pertanian Bogor.

Mardiasmo. (2002). Otonomi dan Manajemen Keuangan Daerah. Yogyakarta: Andi Offset.

Peraturan Menteri Dalam Negeri No. 7 tahun 2008 Tentang Pedoman Tata Cara 
Pengawasan Atas Penyelenggaraan Pemerintah Desa.

Peraturan Menteri Dalam Negeri Nomor 113/2014 tentang Pedoman Pengelolaan Keuangan Desa.

Peraturan Menteri Dalam Negeri Nomor 37/2007 tentang Pedoman Umum Tata Cara Pelaporan dan Pertanggungjawaban Penyelenggaraan Pemerintahan Desa.

Peraturan Menteri Desa PDTT No. 1/2015 tentang Pedoman Kewenangan Berdasarkan Hak Asal Usul dan Kewenangan Lokal Berskala Desa.

Suyatno. (2015). Menyoal Kesiapan Pemerintahan Desa. Tersedia di
https://www.medcom.id/oase/kolom/IK YzVMoN-menyoal-kesiapanpemerintahan-desa [Diakses pada 4 April 2019].

Syachbrani, W. (2012). Akuntansi \& Akuntabilitas Pemerintahan Desa. Tugas Akhir Akuntansi Sektor Publik Magister Sains Akuntansi Universitas Gajah Mada. [Diunduh tanggal 20 April 2019].

Thomas. (2013). Pengelolaan Alokasi Dana Desa Dalam Upaya Meningkatkan Pembangunan Di Desa Sebawang Kecamatan Sesayap Kabupaten Tana Tidung. eJournal Pemerintahan Integratif, Vol. 1 (1) hlm. 51-64. 
